\title{
Penentuan Faktor Kunci Peningkatan Kualitas Air Limbah Industri Makanan Menggunakan Interpretative Structural Modeling (ISM)
}

\author{
Dino Rimantho dan Hera Rosdiana
}

Jurusan Teknik Industri - Universitas Pancasila; e-mail: dino.rimantho@univpancasila.ac.id

\begin{abstract}
ABSTRAK
Industri makanan merupakan salah satu jenis industri manufaktur yang menggunakan berbagai sumber daya dalam operasionalnya dimana dalam prosesnya berpotensi menghasilkan air limbah yang mengandung berbagai senyawa yang dapat menurunkan kualitas lingkungan. Penelitian ini bertujuan untuk menentukan faktor kunci peningkatan kualitas air limbah di industri makanan. Pemilihan alternatif dan analisis strategi menggunakan metode Interpretative Structural Modelling (ISM), dimana metode ini menggunakan penilaian pakar dalam bentuk kuesioner dalam pengambilan datanya. Hasil penelitian menunjukkan bahwa terdapat empat faktor utama dalam upaya peningkatan kualitas air limbah seperti manusia, mesin, metode, material dan lingkungan. Lebih lanjut, berdasarkan hasil analisis dengan metode ISM diperoleh nilai dependent yang rendah dan nilai driver power yang tinggi, maka dapat diketahui faktor kunci dalam peningkatan kualitas air limbah di industri makanan yaitu faktor monitoring harian dalam pengecekan effluent. Sehingga, pemangku kepentingan di industri pengolahan makanan untuk senantiasa melakukan monitoring dan perbaikan proses dalam rangka peningkatan kualitas air limbah yang sesuai dengan baku mutu lingkungan.
\end{abstract}

Kata kunci: Air limbah, Industri makanan, ISM, Kualitas, Faktor kunci

\begin{abstract}
The food industry is one type of manufacturing industry that uses various resources in its operations. The processing process has the potential to produce wastewater containing various compounds that can reduce the quality of the environment. This study aims to determine the key factors to improve the quality of wastewater in the food industry. The selection of key factors is using Interpretative Structural Modeling (ISM) method. This method uses expert judgment in the form of questionnaires in the data retrieval. The results showed that there are four main factors in efforts to improve the quality of wastewater such as human, machine, method, material, and environment. Furthermore, based on ISM method analysis results obtained low dependent value and high power driver value, a key factor in improving the quality of wastewater in the food industry is daily monitoring factor in effluent checking. Thus, the stakeholders in the food processing industry should always monitor and enhancements the process in order to improve the quality of wastewater in accordance with environmental quality standards.
\end{abstract}

Keywords: wastewater, Food Industry, ISM, Quality, Key factor

Citation: Rimantho D., dan Rosdiana H. (2017). Penentuan Faktor Kunci Peningkatan Kualitas Air Limbah Industri Makanan Menggunakan Interpretive Structural Modelling (ISM). Jurnal Ilmu Lingkungan, 15(2), 90-95 doi:10.14710/jil.15.2.90-95

\section{Pendahuluan}

Salah satu kecenderungan utama pada pengembangan industri makanan di abad 21 adalah terciptanya produk yang bermanfaat dan sehat, yang disebut produk makanan fungsional. Beberapa faktor yang secara umum terdapat dalam industri makanan adalah adanya kandungan bahan-bahan yang berfungsi sebagai nutrisi bagi tubuh dan salah satu sumber energi bagi manusia. Selain itu, makanan dapat memiliki fungsi fisiologis yang spesifik yang dapat membantu organisme dalam manusia melawan berbagai penyakit. Salah satu sumber bahan baku dalam industri makanan yang memberikan peluang usaha yang tinggi adalah singkong.

Singkong (Mannihot esculenta crantz) adalah tanaman berkayu dari keluarga tanaman semak dengan bunga kehijau-hijauan (euphorbiaceane) telah menjadi makanan pokok di sebagian besar negara berkembang di sub-Sahara Afrika dan juga sebagian besar negara Asia (Eze dan Azubuike, 2010; Schulthness et al. 2004). Tanaman singkong dikenalkan pada tahun 1650 dari Meksiko dan tumbuh subur dalam system pertanian di Asia Tenggara (Mougeot dan Leveng, 1990). Total produksi singkong di Indonesia sekitar 30\% dari produksi Asia Pasifik dan menjadikan Indonesia 
sebagai salah satu negara eksportir singkong terbesar di dunia. Pada beberapa wilayah tertentu di Indonesia menjadikan singkong sebagai bahan makanan pokok dan juga menjadi bahan baku industri makanan (Pakpahan dan Gunawan, 1992).

Industri makanan merupakan salah satu jenis industri manufaktur yang menggunakan berbagai sumber daya dalam operasionalnya. Oleh karena itu merupakan hal yang penting untuk memastikan bahwa penggunaan bahan baku dan bahan tambah telah dilakukan secara efektif dan efisien. Untuk dapat mencapai tingkat efisiensi dan efektivitas yang optimal dapat dilakukan berbagai macam strategi, misalnya dengan mengimplementasikan teknologi non-limbah, melaksanakan kontrol yang ketat dalam proses produksinya dan lain-lain. Selain itu, aspek yang tidak kalah penting adalah adanya kepastian bahwa proses produksi tidak akan mengganggu keseimbangan lingkungan. Studi yang dilakukan oleh Koshel et al., (1998) menyatakan bahwa salah satu masalah yang signifikan dalam industri makanan adalah pengelolaan air limbah. Lebih lanjut, penelitian yang dilakukan oleh Howeler et al., (2000) menggarisbawahi bahwa secara garis besar industri pengolahan makanan akan menghasilkan sejumlah besar limbah.

Industri makanan pengolahan singkong secara umum berpotensi secara signifikan terhadap penurunan kualitas sumber daya air (Oghenejoboh, 2015). Terdapat banyak industri pengolahan makanan yang menggunakan bahan baku singkong baik dalam skala besar atau kecil di belahan dunia lainnya yang juga mempengaruhi kualitas lingkungan. Penelitian yang dilakukan oleh Osunbitan (2009) menjelaskan beberapa parameter yang berpotensi menurunkan kualitas lingkungan dari industry pengolahan singkong antara lain BOD, Sianida dan mineral. Selanjutnya, beberapa studi menunjukkan adanya sejumlah besar bahan inert yang mengandung senyawa COD yang dihasilkan dari air limbah pencucian singkong (Oghenejoboh, 2012; Okunade dan Adakalu, 2013). Sementara itu, produksi pati singkong menggunakan air dalam volume yang besar yang mengakibatkan pelepasan sejumlah besar air limbah. Air limbah dari pabrik pengolahan pati secara umum mengandung karbohidrat selulosa, senyawa nitrogen dan sianoglikosida. Sianogen dan glikosida mudah terhidrolisis menjadi sianida hidrogen yang beracun bagi hewan air dan menimbulkan ancaman serius terhadap lingkungan (Abiona 2005).

Pencemaran terjadi ketika air limbah yang dibuang dari pengolahan singkong meresap ke dalam lapisan tanah atau mengalir ke sungai atau ketika singkong yang difermentasi di sungai, kolam, maupun di hulu sungai (Oboh, 2006). Lebih lanjut, efek dari air limbah singkong terhadap lingkungan dapat terjadi tidak hanya pada lingkungan perairan, tetapi juga memberikan dampak negatif pada tanaman, udara, ternak peliharaan, dan tanah (Ehiagbonare et al. 2009). Sebagian besar air limbah singkong yang timbul dari industri pengolahan makanan akan bercampur dengan limbah rumah tangga di perairan sungai, sementara yang lainnya meresap ke dalam tanah. Pencemaran air telah menyebabkan sekitar 14.000 kematian per hari, terutama karena pencemaran pada air minum (Pidot, 2006). Pelepasan air limbah dan kontaminan ke dalam badan sungai dapat terjadi melalui sistem drainase, tumpahan cairan, saluran air pembuangan, dan sampah.

Salah satu upaya yang dapat dilakukan untuk mencegah terjadinya penurunan kualitas air limbah yang dihasilkan adalah melakukan proses penjernihan air di instalasi pengolahan air limbah. Proses penjernihan tersebut dapat dilakukan dengan berbagai metode. Tetapi yang terpenting dari proses penjernihan tersebut adalah memastikan bahwa kualitas air limbah yang dihasilkan telah memenuhi baku mutu yang ditentukan oleh Kementerian lingkungan hidup atau Kementerian kesehatan. Untuk mendapatkan kualitas air limbah yang sesuai baku mutu ditentukan oleh berbagai faktor seperti operator pelaksana lapangan, jenis teknologi, karakteristik air limbah, lingkungan dan metode penjernihannya. Dalam mencapai kualitas air yang dihasilkan dari proses penjernihan di unit pengolahan air limbah telah sesuai dengan standar yang ditentukan, sangat penting untuk memahami hubungan timbal balik antara berbagai faktor yang terdapat dalam pengelolaan air limbah. Sehingga, tujuan yang ingin dicapai dalam makalah ini adalah melakukan studi empiris guna mengembangan model structural (ISM) yang memungkinkan indentifikasi dalam mencapai standar kualitas air limbah di industry makanan. Metode ISM diaplikasikan dalam rangka untuk membuat prioritas faktor-faktor secara kualitatif dan membuat usulan struktur hirarki berdasarkan urutan dan kategorinya.

\section{Metode Penelitian}

Pengumpulan data primer dilakukan dengan berbagai cara seperti observasi lapangan, brainstorming dan wawancara dengan berbagai stakeholder baik dari perusahaan dan akademisi. Metode kuesioner dilakukan dengan cara memberikan suatu daftar pertanyaan (angket), baik secara terbuka maupun tertutup, untuk diisi oleh responden (pakar) dimana daftar pertanyaan tersebut sudah dipersiapkan terlebih dahulu. Adapun jumlah pakar yang digunakan dalam penelitian ini adalah sebanyak lima orang. Sementara itu, data sekunder diperoleh dari berbagai sumber pustaka dan dokumen yang terkait dengan penelitian.

Analisis data menggunakan metode Interpretative Structural Modelling yang dikembangkan oleh Saxena (1992) dalam Eriyatno (1999). Data teknis Interpretative Structural Modelling adalah kumpulan pendapat pakar sebagai panelis sewaktu menjawab tentang keterkaitan antar elemen. 
Permodelan Interpretasi Struktural menganalisis elemen-elemen sistem dan memecahkannya dalam bentuk grafik dari hubungan langsung antar elemen dan tingkat hirarki. Elemenelemen dapat merupakan tujuan kebijakan, target organisasi, faktor-faktor penilaian dan lain-lain. Hubungan langsung dapat dalam konteks-konteks yang beragam (Marimin, 2008).

Teknik ISM ini dapat digunakan untuk melakukan analisis program yang sesuai dengan visi dan misi. Secara garis besar teknik ISM dibagi menjadi dua bagian, yaitu: klasifikasi elemen dan penyusunan hirarki. Langkah pertama yang perlu dilakukan dalam analisis ISM adalah menentukan elemen-elemen yang sesuai dengan permasalahan yang ada. Selanjutnya disusun sub-elemen pada setiap elemen yang terpilih. Pemilihan elemen dan penyusunan sub elemen dilakukan dari hasil diskusi dengan pakar. Hasil penilaian tersebut tersusun dalam Structural Self Interaction Matrix (SSIM) yang dibuat dalam bentuk tabel Rechability Matrix (RM) dengan mengganti V, A, X, O menjadi bilangan 1 dan 0. Klasifikasi elemen didasarkan pada Structural Self Matrix (SSM) yang dibuat berdasarkan sistem VAXO, yaitu :

$\mathrm{V}$ jika eij $=1$ dan eji $=0$;

A jika eij $=0$ dan eji $=1$;

$\mathrm{X}$ jika eij $=1$ dan eji $=1$;

0 jika eij $=0$ dan eji $=0$

Matrik kemudian dirubah menjadi matrik tertutup. Hal ini dilakukan untuk mengoreksi matriks tersebut memenuhi kaidah transitivity yaitu jika A mempengaruhi $\mathrm{B}$ dan $\mathrm{B}$ mempengaruhi $\mathrm{C}$, maka $\mathrm{A}$ harus mempengaruhi $\mathrm{C}$.

Nilai 1 berarti ada hubungan kontekstual antara elemen ke -i dan elemen ke-j, sedangkan eij = 0 berarti tidak ada hubungan kontekstual antar elemen ke-i dengan elemen ke-j. Kemudian SSM diubah menjadi reachability matrix dengan merubah VAXO menjadi 1 dan 0, selanjutnya dilakukan pengujian terhadap aturan transivity, sampai terjadi matrik yang tertutup. Matrik yang telah memenuhi transivity dilanjutkan pengolahannya untuk mendapatkan matrik reachability, untuk mendapatkan Driver Power (DP) dan Depedence (D). Tahap terahir adalah mengelompokkan sub-sub elemen kedalam 4 sektor (Saxena,

1994) :

a. Weak driver _ weak Dependent variables (AUTONOMOUS), peubah di sektor ini umumnya tidak berkaitan dengan sistem, hubungannya sedikit.

b. Weak driver strongly-Dependent variables (DEPENDENT), peubah yang masuk kedalam kelompok ini merupakan peubah tak bebas,

c. Strong driver strongly dependent variables (LINKAGE), peubah pada sektor ini harus dikaji secara hati-hati karena interaksinya dapat memberikan dampak dan umpan balik terhadap sistem

d. Strong driver weak Dependent variables (INDEPENDENT) peubah dalam sektor ini memiliki pengaruh yang kuat dalam sistem dan sangat menentukan keberhasilan program.

\section{Hasil dan Pembahasan}

Berdasarkan hasil diskusi dengan pakar, pihak terkait dan penelitian di lapangan diperoleh berbagai factor yang berpotensi menghasilkan air limbah yang kualitasnya memenuhi baku mutu lingkungan. Adapun faktor tersebut antara lain, faktor manusia, mesin, material, peralatan dan lingkungan. Dari kelima faktor tersebut selanjutnya dikembangkan dan diperoleh informasi tentang sub faktor seperti, kurangnya tenaga kerja, minimnya pengetahuan tentang pengolahan limbah, tidak pernah mendapat training yang bersifat teknis, aerator tidak mampu bekerja secara maksimal, tidak adanya pompa penyedot lumpur pada tangki sedimentasi 1 dan 2 , tidak ada alat Flowmeter, tidak ada jadwal maintenance, luas area IPAL terbatas, volume limbah produksi tinggi, tidak menyediakan uji interal, air limbah mempunyai karakteristik yang berbeda, tidak ada monitoring harian dalam pengecekan effluent.

Berdasarkan hasil kuesioner yang telah diisi oleh para responden selanjutnya dilakukan pembuatan matrik Structural Self Interaction Matrix (SSIM) sebagaimana tabel 1.

Selanjutnya, berdasarkan tabel 1 tentang matrik SSIM selanjutnya dibuat dalam bentuk tabel Rechability Matrix (RM) dengan mengganti V, A, X, O menjadi bilangan 1 dan 0 . Sehingga, diperoleh hasil sebagaimana tabel 2 .

Kemudian, berdasarkan hasil interpretasi dari matrik Rechability Matrix (RM) akhir maka dapat disusun suatu hirarki keterhubungan antar faktor peningkatan kualitas air limbah di industri makanan yang dapat dijelaskan pada gambar 1 .

Dari gambar 1. Memberikan informasi bahwa monitoring harian dalam pengecekan effluent (A12) merupakan faktor yang mempunyai nilai driver power paling tinggi, sehingga elemen ini dapat menjadi pendorong yang mempengaruhi keberhasilan faktor-faktor yang lain yaitu tidak adanya pompa penyedot lumpur pada tangki sedimentasi 1 dan 2 (A5) serta tidak pernah mendapat training yang bersifat teknis (A3).

Peningkatan kualitas air limbah yang dihasilkan dari proses pengolahan makanan merupakan salah satu upaya yang dilakukan dalam kaitannya dengan perlindungan kualitas lingkungan dan kesehatan manusia. Kualitas air limbah yang dihasilkan dari proses pengolahan harus senantiasa mengacu pada Keputusan Menteri Negara Lingkungan Hidup No. 51 tahun 1995 tentang Baku Mutu Limbah Cair Bagi Kegiatan Industri. 
Rimantho D dan Rosdiana H. (2017). Penentuan Faktor Kunci Peningkatan Kualitas Air Limbah Industri Makanan Menggunakan Interpretive Structural Modelling (ISM). Jurnal IImu Lingkungan, 15(2), 90-95, doi:10.14710/jil.15.2.90-95

Tabel 1 Matrik Structural Self Interaction Matrix (SSIM)

\begin{tabular}{|c|c|c|c|c|c|c|c|c|c|c|c|c|}
\hline & A1 & A2 & A3 & A4 & A5 & A6 & A7 & A8 & A9 & A10 & A11 & A12 \\
\hline A1 & & 0 & 0 & 0 & 0 & 0 & 0 & 0 & 0 & 0 & 0 & $\mathrm{X}$ \\
\hline A2 & & & $X$ & A & A & 0 & 0 & V & V & V & 0 & $X$ \\
\hline A3 & & & & $\mathrm{V}$ & V & V & $\mathrm{V}$ & 0 & V & $\mathrm{V}$ & V & $X$ \\
\hline A4 & & & & & $X$ & $\mathrm{X}$ & $X$ & $X$ & $X$ & A & $\mathrm{X}$ & X \\
\hline A5 & & & & & & X & $X$ & $\mathrm{~V}$ & $X$ & V & X & $X$ \\
\hline A6 & & & & & & & $X$ & $X$ & $X$ & $\mathrm{X}$ & $X$ & $X$ \\
\hline A7 & & & & & & & & 0 & $X$ & V & $X$ & $X$ \\
\hline A8 & & & & & & & & & $X$ & 0 & $X$ & X \\
\hline A9 & & & & & & & & & & $\mathrm{V}$ & $X$ & X \\
\hline A10 & & & & & & & & & & & $\mathrm{X}$ & $X$ \\
\hline A11 & & & & & & & & & & & & $X$ \\
\hline A12 & & & & & & & & & & & & \\
\hline
\end{tabular}

Sumber data diolah dari kuesioner

Tabel 2 Matrik Rechability Matrix (RM)

\begin{tabular}{|c|c|c|c|c|c|c|c|c|c|c|c|c|c|c|}
\hline & A1 & $\mathrm{A} 2$ & A3 & A4 & A5 & A6 & A7 & A8 & A9 & A10 & A11 & A12 & $\begin{array}{l}\text { Driven } \\
\text { Power }\end{array}$ & Rangking \\
\hline A1 & 1 & 0 & 0 & 0 & 0 & 0 & 0 & 0 & 0 & 0 & 0 & 1 & 2 & 7 \\
\hline A2 & 0 & 1 & 1 & 0 & 0 & 0 & 0 & 1 & 1 & 1 & 0 & 1 & 6 & 5 \\
\hline A3 & 0 & 1 & 1 & 1 & 1 & 1 & 1 & 0 & 1 & 1 & 1 & 1 & 10 & 2 \\
\hline A4 & 0 & 1 & 0 & 1 & 1 & 1 & 1 & 1 & 1 & 0 & 1 & 1 & 9 & 3 \\
\hline A5 & 0 & 1 & 0 & 1 & 1 & 1 & 1 & 1 & 1 & 1 & 1 & 1 & 10 & 2 \\
\hline A6 & 0 & 0 & 0 & 1 & 1 & 1 & 1 & 1 & 1 & 1 & 1 & 1 & 9 & 3 \\
\hline A7 & 0 & 0 & 0 & 1 & 1 & 1 & 1 & 0 & 1 & 1 & 1 & 1 & 8 & 4 \\
\hline A8 & 0 & 0 & 0 & 1 & 0 & 1 & 0 & 1 & 1 & 0 & 1 & 1 & 6 & 5 \\
\hline A9 & 0 & 0 & 0 & 1 & 1 & 1 & 1 & 1 & 1 & 1 & 1 & 1 & 9 & 3 \\
\hline A10 & 0 & 0 & 0 & 1 & 0 & 1 & 0 & 0 & 0 & 1 & 1 & 1 & 5 & 6 \\
\hline A11 & 0 & 0 & 0 & 1 & 1 & 1 & 1 & 1 & 1 & 1 & 1 & 1 & 9 & 3 \\
\hline A12 & 1 & 1 & 1 & 1 & 1 & 1 & 1 & 1 & 1 & 1 & 1 & 1 & 12 & 1 \\
\hline Dependence & 2 & 5 & 3 & 10 & 8 & 10 & 8 & 8 & 10 & 9 & 10 & 12 & & \\
\hline Hirarki & 7 & 5 & 6 & 2 & 4 & 2 & 4 & 4 & 2 & 3 & 2 & 1 & & \\
\hline
\end{tabular}

Sumber data diolah dari kuesioner

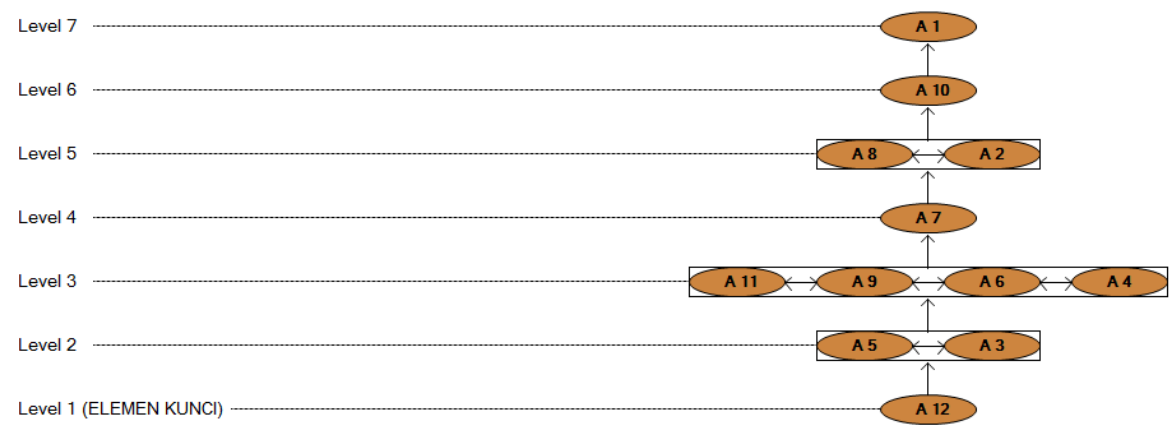

Gambar 1 Struktur hierarki antar faktor peningkatan kualitas air limbah di industri makanan

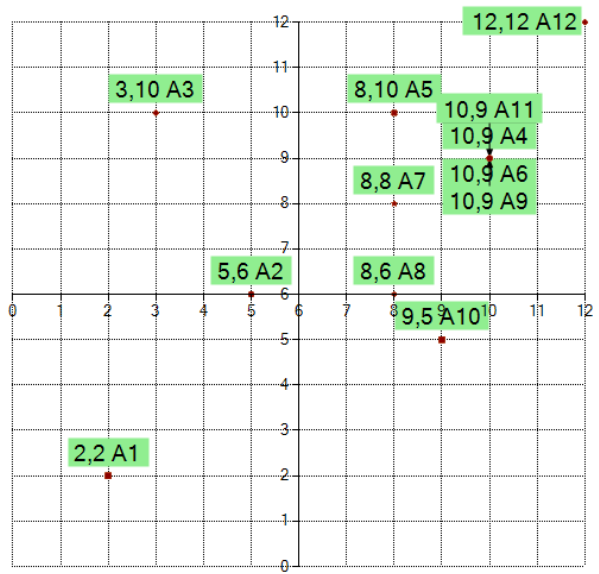

Gambar 2 Matrik Driver-Power dependent faktor peningkatan kualitas air limbah di industri makanan 
Selanjutnya dalam keputusan menteri tersebut juga menjelaskan adanya kewajiban bagi pelaku industri untuk melaksanakan beberapa aktivitas seperti:

a. Melakukan pengelolaan limbah cair sehingga mutu limbah cair yang dibuang ke lingkungan tidak melampaui baku mutu limbah cair yang telah ditetapkan.

b. Membuat saluran pembuangan limbah cair yang kedap air sehingga tidak terjadi perembesan limbah cair ke lingkungan.

c. Memasang alat ukur atau laju air limbah cair dari melakukan pencatatan debit harian limbah cair tersebut.

d. Tidak melakukan pengenceran limbah cair, termasuk mencampurkan buangan air bekas pendingin ke dalam aliran pembuangan limbah cair.

e. Memeriksakan kadar parameter baku mutu limbah cair secara periodik sekurangkurangnya satu kali dalam sebulan.

f. Memisahkan saluran pembuangan limbah cair dengan saluran limpahan air hujan.

g. Melakukan pencatatan produksi bulanan senyatanya.

h. Menyampaikan laporan tentang catatan debit harian, kadar parameter baku mutu limbah cair, produksi bulanan senyatanya, sekurang-kurangnya tiga bulan sekali kepada kepala Bapeda, Gubernur, instansi teknis yang membidangi industri, dan instansi lain yang dianggap perlu sesuai dengan peraturan perundang-undang yang berlaku.

Dengan mengacu dari hasil pengolahan dengan metode ISM menunjukkan bahwa kegiatan monitoring pada effluent air limbah merupakan factor kunci yang menjadi perhatian. Hal ini sesuai dengan poin pada keputusan menteri lingkungan hidup tersebut.

Pemantauan dan pengujian kualitas air limbah dapat dilakukan pada beberapa tahapan, misalnya monitoring kualitas dari sumber, proses pengolahan dan effluent.

a. Monitoring sumber

Dengan dilakukan aktivitas pemantauan pada sumber keluarnya air limbah dari aktivitas proses produksi akan mendapatkan beberapa keuntungan seperti diketahuinya lebih awal volume, karakteristik air limbah dan konsentrasi senyawa yang dihasilkan. Sehingga, dengan diketahuinya hal tersebut akan memberikan keuntungan bagi perusahaan pada proses berikutnya maupun dapat menjadi informasi balik bagi proses sebelumnya.

b. Pemantauan pada proses pengolahan air limbah pada tiap unit

Air limbah yang masuk dalam unit pengolahan air limbah harus dianalisis secara teratur pada tiap tahapan proses pengolahan. Hal ini dapat memungkinkan operator dapat memantau volume, kualitas dari masing-masing parameter air yang masuk dan dapat menyesuaikan prosesnya dalam rangka efektivitas pemantauan atau monitoring. Pengujian dapat dilakukan di berbagai tahap proses pengolahan baik secara fisik, kimia dan biologi.

c. Monitoring pada saluran pembuangan di badan sungai

Pelaksanaan monitoring effluen pada saluran pembuangan di badan sungai harus dilakukan guna memastikan bahwa limbah yang dibuang ke badan sungai telah memenuhi baku mutu lingkungan. Pengambilan sampel dapat dilakukan setidak-tidaknya sebulan sekali. Analisis sampel air limbah yang dilakukan misalnya kadar $\mathrm{pH}$, tingkat penyerapan oksigen, koliform fekal dan berbagai unsur kimia penting.

\section{Kesimpulan}

Dari uraian pembahasan dapat diambil beberapa kesimpulan bahwa terdapat 12 faktor yang terdapat dalam peningkatan kualitas air limbah dari industry makanan, misalnya kurangnya tenaga kerja, minimnya pengetahuan tentang pengolahan limbah, tidak pernah mendapat training yang bersifat teknis, aerator tidak mampu bekerja secara maksimal, tidak adanya pompa penyedot lumpur pada tangki sedimentasi 1 dan 2, tidak ada alat Flowmeter, tidak ada jadwal maintenance, luas area IPAL terbatas, volume limbah produksi tinggi, tidak menyediakan uji interal, air limbah mempunyai karakteristik yang berbeda, tidak ada monitoring harian dalam pengecekan effluent. Berdasarkan hasil penilaian pada pakar diperoleh nilai dependent yang rendah dan nilai driver power yang tinggi, maka dapat diketahui faktor kunci dalam peningkatan kualitas air limbah di industri makanan yaitu faktor monitoring harian dalam pengecekan effluent (A12). Selanjutnya, dapat disarankan bagi pemangku kepentingan di industry pengolahan makanan untuk senantiasa melakukan monitoring dan perbaikan proses dalam rangka peningkatan kualitas air limbah yang sesuai dengan baku mutu lingkungan.

\section{DAFTAR PUSTAKA}

Abiona, O. O., Sanni, L. and Bamgbose, 0. 2005. An evaluation of microbial load, heavy metals and cyanide contents of water sources, effluent and peels from three cassava processing locations. International Journal of Food and Agricultural Environment Vol.3, 207-208

Ehiagbonare J.E., Enabulele S.A., Babatunde B. B., Adjarhore R. 2009. Effect of Cassava Effluent on Okada Denizens. Sci. Res. Essay 4(4):310-313. Terdapat pada:

http://www.academicjournals.org/sre/PDF/pdf200 9/Apr/Ehiagbonare\%20et\%20al.pdf (Diakses 17November 2017) 
Eriyatno. 1999. Ilmu Sistem. Meningkatkan Mutu dan Efektivitas Manajemen. IPB Press, Bogor, hlm 79.

Eze SO, Azubuike A. 2010. Assessment of the physicochemical properties and applicartions of some cassava varieties. Research Journal of Applied Sciences. 5(4):309.

Howeler RH, Oates CG, Allen AC. 2000. An Assessment of the Impact of cassava production and processing on the Environment and Biodiversity. Proceed. Validation Forum Global Cassava Dev. Strategy, 5: 1-9.

Koshel M., Shmatko T. and others. 1998. Effective clearance of wastewater // Food and processing industry. -- No 6. - P. 27.

Marimin. 2008. Teknik dan Aplikasi Pengambilan Keputusan Kriteria Majemuk. Grassindo. Jakarta.

Mougeot E, Leveng P. 1990. Marketing of rice, cassava and coffee in Lampung, Indonesia. CGPRT Centre, Bogor. p.123.

Oboh G. 2006. Nutrient Enrichment of Cassava Peels using a Mixed Multure of Maccharomyces Cerevisae and Lactobacillus spp. Solid Media Fermentation. Electr. J. Biotechnol. 9(1):46-49.

Oghenejoboh K.M. 2015. Effects of Cassava Wastewater on the Quality of Receiving Water Body Intended for Fish Farming, British Journal of Applied Science \& Technology, 6(2): 164-171.

Oghenejoboh KM. 2012. Effects of starch fermentation on the shelf-life of cassava based adhesive. British Biotechnology Journal. 2(4):257-268.

Okunade DA. and Adakalu KO. 2013. Physico-Chemical Analysis of Contaminated Water Resources Due to Cassava Wastewater Effluent Disposal, European Journal of Science and Technology, Vol. 2 (6):75-78

Osunbitan JA. 2009. Suitability of Runoff water quality for Irrigation from a plot treated with cassava effluents. J. Environ. Hydrol., 17(18).

Pakpahan A, Gunawan M. 1992. Introduction and conceptual framework for cassava marketing research. In: Cassava marketing in Indonesia. (Pakpahan A, Gunawan M, Djauhari A, Pasaribu SM, Nasution Aladin, Friyanto Supena eds). Monograph series No.2, Center for Agro-Socioeconomic Research, Agency for Agricultural Research and Development, Bogor pp. 20-29.

Pidot J. R. 2006. Global Warming in the Courts - An Overview of Current Litigation and Common Legal Issues. Georgetown University Law Center.

Schulthness F, Chabi-Olaye A, Gounou S. 2004. Multitrophic levels intractions in cassavamaize mixed cropping system in Humid Tropics of West Africa, Bull. Entomol. Res. 94:261-263. 